$\begin{array}{llllllllllllll}\text { A C T A S H E M I C A S C A N D I N A V I C A } \quad 4 \quad(1950) & 52-54\end{array}$

\title{
The Food Sparing Effect of Liver Extracts on Rats. II
}

\author{
GUN NAR ÄGEN \\ Institute of Medical Chemistry, University of Uppsala, Sweden
}

\begin{abstract}
Tn two recent papers it was shown that the daily administration of about $10.2 \mathrm{~g}$ of a catheptic casein hydrolysate or $0.06 \mathrm{~g}$ of a liver extract to young rats significally increased the weight gain per $g$ food eaten ${ }^{1,2}$. In both investigations the active material was administered with pipettes and the weight of the rats at the beginning of the experiments was about $60-70 \mathrm{~g}$. In an unpublished series of experiments on full-grown animals a food sparing effect was not noticed. Accordingly, it was of interest to observe the effect of a liver extract in later stages of growth than used in the previous experiments ${ }^{1,2}$. It was also of importance to observe if the effect was present when the food was fortified with the extract.
\end{abstract}

\section{EXPERIMENTAL}

The animals, young albino rats, were kept in individual cages. Water and the commercial mouse bread described by Gard ${ }^{3}$ were given ad libitum. Individual animal weight and food consumption were determined daily. Each $\mathrm{ml}$ of the liver extract used in this investigation contained $0.27 \mathrm{~g}$ of solids with a nitrogen content of $25 \mathrm{mg}$ per $\mathrm{ml}$. At the beginning of the first series of experiments the weight of the rats was about $80 \mathrm{~g}$. The experimental time was 15 days and $0.3 \mathrm{ml}$ of the liver extract was daily administered with pipettes. The results are given in Table 1 .

In a second series the liver extract was added to the bread in amounts calculated to give each animal the content of $0.3 \mathrm{ml}$ of extract when the daily food consumption was about $16 \mathrm{~g}$. The same rats as in the previous experiment were used and the calculations were based on the figures obtained in that experiment. At the beginning of the new experiment the weight of the rats was about $135 \mathrm{~g}$ and the daily food consumption of the two groups of animals was about the same $(22 \mathrm{~g})$. The experimental time in this later experiment was 15 days. The results are given in Table 2 . 
Table 1. Growth of rats on a mixed diet with the addition of liver extract by means of pipettes.

\begin{tabular}{|l|c|c|c|c|}
\hline \multicolumn{1}{|c|}{ Group } & $\begin{array}{c}\text { No. of } \\
\text { animals }\end{array}$ & $\begin{array}{c}\text { Average daily } \\
\text { weight gain }\end{array}$ & $\begin{array}{c}\text { Average daily } \\
\text { food consumption }\end{array}$ & $\begin{array}{c}\text { Weight gain per } \\
\text { g food eaten }\end{array}$ \\
\hline Liver & 15 & $2.9 \pm 0.20^{*}$ & $12.7 \pm 0.22 *$ & $0.23 \pm 0.015 *$ \\
Control & 15 & $2.6 \pm 0.15$ & $19.6 \pm 0.12$ & $0.13 \pm 0.008$ \\
\hline
\end{tabular}

There was no significant difference in daily weight gain between the liver and the control group in any of the two experiments. The food sparing effect of the liver extract was quite obvious in both series. The impression gained from this and the previous investigations ${ }^{1,2}$ is that the food sparing effect develops during the three first days of an experiment and remains for about five days when the treatment is discontinued.

A more complete interpretation of the results obtained in this and previous investigations must await the isolation and identification of the factor or factors responsible for the effect. As already mentioned liver extracts must contain several biologically active factors which are not identified (Ågren ${ }^{4}$ ). The food sparing effect could be related to some newly identified factor as vitamin $B_{12}$ which is present in most liver extracts and not supplied in sufficient amounts with the mouse bread. However, the effect is also present in enzyme hydrolyzed casein which is not considered to be rich in vitamin $\mathbf{B}_{12}$. Experiments performed with the pure vitamin or vitamin concentrates on chickens ${ }^{5}$ and weanling pigs ${ }^{6}$ showed that this factor stimulated the growth but the average daily food consumption of the animals given the vitamin increased or was unchanged. It may also be mentioned that Gard's mouse bread contains meat powder and milk both potential sources of vitamin $B_{12}$.

Table 2. Growth of rats on a mixed diet given as bread fortified with liver extract.

\begin{tabular}{|l|c|c|c|c|}
\hline \multicolumn{1}{|c|}{ Group } & $\begin{array}{c}\text { No. of } \\
\text { animals }\end{array}$ & $\begin{array}{c}\text { Average daily } \\
\text { weight gain }\end{array}$ & $\begin{array}{c}\text { Average daily } \\
\text { food consumption }\end{array}$ & $\begin{array}{c}\text { Weight gain per } \\
\text { g food eaten }\end{array}$ \\
\hline Liver & 15 & $2.2 \pm 0.10^{*}$ & $16.5 \pm 0.14 *$ & $0.13 \pm 0.008^{*}$ \\
Control & 15 & $1.6 \pm 0.13$ & $22.0 \pm 0.16$ & $0.07 \pm 0.007$ \\
\hline
\end{tabular}

* The velues in these columns are the means and the standard errors. 
A possible explanation is that some factor or factors in the liver extract, either alone or in cooperation with the pituitary growth hormone, will maintain the nitrogen metabolism on a more efficient level by reducing the rate of oxidative disposal of amino acids. A similar mechanism has also been postulated by Totter et al. ${ }^{7}$ in discussing the possible function of folic acid. A relationship to the function of vitamin A may also exist. Evidence was recently presented by Mayer and Krehl ${ }^{8}$ that this vitamin participates in the control of the food utilization. Furthermore Cabell and Ellis ${ }^{9}$ investigated the efficiency of certain A-deficient diets when supplemented with vitamin A and found the lack of a factor which could be furnished by liver extracts.

\section{SUMMARY}

Growing rats fed on mouse bread fortified with small amounts of a liver extract significantly increased the weight gain per $\mathrm{g}$ food eaten. After discontinuing the administration of liver the food sparing effect was of about five days duration.

The investigation was supported by a grant for medical research from the Swedish Medical Research Council. The technical assistance of Mr. Thore Persson and Mr. C. F. Skjoldebrand is greatfully acknowledged.

\section{REFERENCES}

1. Agren, G. Acta Chem. Scand. 1 (1947) 69.

2. Aggren, G. Acta Physiol Scand. 18 (1949) 337.

3. Gard, S. Acta Path. Microbiol. Scand. Suppl. 54 (1944) 123.

4. Ågren, G. Acta Physiol. Scand. 17 (1949) 55.

5. Ott, W. H., Riches, E. L., and Wood, T. R. J. Biol. Chem. 174 (1948) 1047.

6. Luecke, R. W., Mc Millen, W. N., Thorp, F., and Boniece, J. R. Science 110 (1949) 139.

7. Totter, J. R., Amos, E. S., and Keith, C. K. J. Biol. Chem. 178 (1949) 847.

8. Mayer, J., and Krehl, W. A. Yale J. Biol. and Med. 20 (1948) 403.

9. Cabell, C. R., and Ellis, N. R. Proc. Soc. Exptl. Biol. Med. 65 (1947) 117.

Received November 18, 1949. 